UDK 811.163.42’367(091)

Izvorni znanstveni rad

Rukopis primljen 3. XII. 2018.

Prihvaćen za tisak 28. V. 2019.

https://doi.org/10.31724/rihjj.45.2.16

\title{
Ana Mihaljević
}

Staroslavenski institut

Demetrova ulica 11, HR-10000 Zagreb

amihaljevic@stin.hr

\section{LATINSKI UTJECAJI NA SINTAKSU ZAVISNOSLOŽENIH REČENICA U HRVATSKOGLAGOLJSKIM TEKSTOVIMA $^{1}$}

U radu se analizira utjecaj latinskoga na sintaksu hrvatskoglagoljskih tekstova prevedenih s latinskoga. Pri prevođenju zavisnih rečenica s latinskoga na hrvatski crkvenoslavenski prevoditelji uglavnom doslovno prenose rečenice ne mijenjajući njihovu strukturu. Međutim, dva su glavna problema koja se pojavljuju pri prevođenju. Prvi je problem kako prevesti konjunktiv koji se pojavljuje u velikome broju zavisnih rečenica, a koji nema formalni korespondent u hrvatskome crkvenoslavenskome. Drugi je problem kako prevesti pojedine veznike jer se značenja i funkcije pojedinih veznika u latinskome ne podudaraju s pojedinim veznicima u hrvatskome crkvenoslavenskom. Pri prevođenju je veznika problem što se u latinskome isti veznik može pojavljivati u raznim vrstama zavisnih rečenica, a u svakome kontekstu u hrvatskome crkvenoslavenskom značenjski mu odgovara drugi veznik. Osobito su česte nedoumice pri prevođenju vrlo čestih latinskih veznika ut, cum i quia te katkad hrvatski prevoditelj pogrešno prevodi rečenicu pod utjecajem tipičnoga značenja koji veznik u latinskome ima. U radu se analizira uporaba vremena i veznika u zavisnim rečenicama, odnos izričnih rečenica i konstrukcija s infinitivom i drugi latinski utjecaji u sintaksi zavisnosloženih rečenica. Korpus uključuje biblijske knjige Esteru i Makabejce, apokrife Život Adama i Eve, Nikodemovo evanđelje i Protoevanđelje Jakovljevo, hagiografske tekstove Čtenie s(ve)te Margarite, Čistilište svetoga Patricija i Život Marije Magdalene te brevijarsku službu u čast sv. Anti.

\footnotetext{
1 Tekst je nastao na temelju autoričine neobjavljene doktorske disertacije (Mihaljević 2018).
} 


\section{Uvod}

Pri prevođenju s latinskoga na hrvatski crkvenoslavenski prevodi se s jednoga književnog jezika na drugi, od kojih nijedan nije prevoditeljima materinski. ${ }^{2}$ Zbog toga su prevoditelji osim latinskoga i pod utjecajem govornoga hrvatskog jezika. Prevoditelju je osim jezičnoga potrebno i teološko znanje jer se uglavnom prevode vjerski tekstovi. Zato je često doslovno i vjerno prevođenje. Razlog tomu može biti i činjenica da crkvenoslavenski nije bio priznati sveti jezik i zato se smatralo da se treba što vjernije držati izvornika kako se ne bi nehotice promijenile vjerske poruke (Grickat 1972: 18). U tekstovima se očituju dvije suprotne težnje: što vjernije prevesti latinski tekst i držati se crkvenoslavenskih norma (Páclová 1970). Osobito je zanimljivo pritom razmotriti prijevode oblika i struktura koje se u dvama jezicima razlikuju.

Metodologija rada podređena je opisu građe te je uglavnom deskriptivna, interpretativna i kontrastivna (Kovačević 2016: 72). Primjenjuju se i spoznaje iz područja kontaktne lingvistike (osobito Thomason 1988, 2001, 2010, Sankoff 2001, Winford 2003) te one o mogućnosti promjene sintakse jednoga jezika pod utjecajem drugoga (Prince 1988, 1992, 1998, Silva-Corvalán 1993, 1994, 1998, 2008, Kroch 2001, Sakel i Matras 2007). Rad se oslanja i na radove iz teorije prevođenja (Catford 1965, Ivir 1978, 1990, Nida i Taber 2003, Kranich 2014), osobito teorije prevođenja koje se temelji na korpusu. ${ }^{3}$ Polazište je za opis latinskoga gramatika Gortana, Gorskoga i Pauša (2005).

Korpus se sastoji od niza hrvatskoglagoljskih tekstova različitoga tipa i sadržaja koji su prevedeni s latinskoga: biblijske knjige Estera i Makabejci ${ }^{4}$ apokrifi Život Adama i Eve, ${ }^{5}$ Nikodemovo evanđelje i Protoevanđelje Jakovljevo, ${ }^{6}$ hagiografski tekstovi Čtenie s(ve)te Margarite, Čistilište svetoga Patricija i Život Marije Magdalene $e^{7}$ te brevijarska služba u čast sv. Anti. ${ }^{8}$ Osim tih tekstova dio je

\footnotetext{
2 O odnosu latinskoga i crkvenoslavenskoga v. i Galabov 1973, Keipert 1987, 1996, Matějka 1966, 1968, 1971. O odnosu latinskoga i hrvatskoga crkvenoslavenskog v. Tandarić 1993, Vela i Eterović 2013, Mihaljević 2011c.

3 Engl. corpus-based translation studies. V. Laviosa 2003: 45.

4 O tekstovima je pisala Badurina Stipčević 1999, 2004, 2006, 2009, 2012.

O tekstu je pisala Turkalj 2008.

O tekstu je pisala Badurina Stipčević 2008.

O jeziku Života Marije Magdalene v. A. Mihaljević 2014.

8 Pojedini su tekstovi izdani i u Badurina Stipčević 2013. i Dürrigl 2013.
} 
pojava istražen na građi za Rječnik crkvenoslavenskoga jezika hrvatske redakcije, u kojemu su obrađeni i pojedini veznici. ${ }^{9} \mathrm{U}$ radu se zbog opsega građe navode samo ogledni primjeri pojava.

U radu se analizira prevođenje zavisnih rečenica s latinskoga, a osobita je pozornost posvećena prijevodu veznika i konjunktivnih oblika. ${ }^{10}$ Dosezi latinskoga utjecaja bit će prikazani po vrsti rečenica. Glagolski su oblici glosirani u primjerima kojima se oprimjeruju njihovi načini prevođenja sljedećim kraticama: AOR $=$ aorist, $\mathrm{COND}=$ kondicional, FUTII $=$ futur II., IMP $=$ imperativ, IMPERF $=$ imperfekt, $\mathrm{INF}=$ infinitiv, $\mathrm{PERF}=$ perfekt, $\mathrm{PLPF}=$ pluskvamperfekt, $\mathrm{PP}=$ prošli particip, $\mathrm{PRESP}=$ particip prezenta, $\mathrm{PRS}=$ prezent, $\mathrm{SBJV}=$ konjunktiv.

\section{Zavisnoupitne rečenice}

U latinskome se zavisnoupitne rečenice smatraju iznutra zavisnima i uz sebe zahtijevaju konjunktiv prema pravilima o slaganju vremena. Veznici su latinskih zavisnoupitnih rečenica upitne čestice, zamjenice i prilozi. Na hrvatski se crkvenoslavenski najčešće prevode doslovno, a struktura rečenice vjerno prati latinsku. Nedoumice se pojavljuju najčešće pri prevođenju konjunktiva.

Zavisnoupitne rečenice uvedene zamjenicom quid, ovisno o podrijetlu i ulozi teksta, prevode se odnosnim zamjenicama, crkvenoslavenskim čto ili hrvatskim (čakavskim) ča. U trima se rečenicama iz teksta Čtenie sv. Margarite pojavljuje isti latinski tekst quid illi nocui s indikativnim glagolom, u kojemu prevoditelj, kako ne bi dosadio čitatelju, svaki put mijenja red riječi. Takav je prijevod jedna od značajka prijevodne tehnike u kojoj je vidljiva težnja varijaciji pri prijevodu konstrukcija koje se ponavljaju.

$\mathrm{U}$ primjeru recordatus est Vasthi, et quae fecisset ${ }_{\mathrm{SBJV.PLPF}}$, vel quae passa esset $_{\mathrm{SBJV.PLPF}}\left(\right.$ Est 2,1): vspomenu se vasta c(êsa)rica êže stvorila be $\hat{\mathrm{PLPF}}_{\mathrm{PL}} \cdot$ ili êže trpêla $b i_{\text {COND }}($ BrVO 402a) vezničko je sredstvo odnosna zamjenica quae, koja je prevedena zamjenicom êže, koja je njezin formalni korespondent, umjesto jedninskoga oblika, koji bi bio prototipan u hrvatskome crkvenoslavenskom. U

\footnotetext{
RCJHR 2000. i 2014. Zahvaljujem Staroslavenskomu institutu na omogućavanju pristupa građi.

10 O prevođenju konjunktiva v. Gadžijeva i dr. 2014: 359, Mihaljević 2006, 2009.
} 
tome je primjeru prvi konjunktiv preveden pluskvamperfektom, a drugi kondicionalom.

Rečenice koje započinju veznikom unde mogu se smatrati i zavisnoupitnima i odnosnima jer pretpostavljaju mjesto na koje se odnosna rečenica nadovezuje. U nekim se primjerima takve rečenice s konjunktivom mogu tumačiti kao odnosne rečenice s namjernim smislom. U takvim rečenicama glagol glavne rečenice nije tipičan za zavisnoupitne rečenice. Odnosnost rečenica vidljiva je u primjeru u kojemu je unde prevedeno prijedložnom skupinom od kih: et ut habeant fructum, unde viverent ipsi et omnes generationes eorum (Vita Adae et Evae): da b(u)de imeti plod'b od kih' plodi žiti vačnut' on' i vasb rod' nego po nem' (CŽg 35r).

U klasičnome latinskom uz neke glagole kao upitni veznik u značenju suvremene hrvatske čestice $l i$ stoji veznik si. U gramatikama se navodi da su najčešći takvi glagoli expectare, experiri, temptare, conari, dakle glagoli koji označuju čekanje ili pokušavanje. ${ }^{11} \mathrm{U}$ takvim se slučajevima veznikom si naglašava čuđenje i iščekivanje (Pinkster 2015: 627). ${ }^{12}$ Vjerojatno je takva uporaba veznika si u zavisnoupitnim rečenicama povezana s činjenicom da si izvorno dolazi u pogodbenim rečenicama, kojima se ne izriče stvarni događaj, nego se uvijek podrazumijeva određeni stupanj nesigurnosti jer se čak i u stvarnim rečenicama zavisnom rečenicom izriče uvjet koji se mora ispuniti da bi se ostvarila glavna rečenica, ali se ne izriče stav o stvarnoj ispunjenosti toga uvjeta. ${ }^{13}$ Pogodbena rečenica uvijek podrazumijeva i mogućnost suprotnoga onomu što je rečenicom izrečeno. Na primjer rečenica Ako ne bude padala kiša, ići ćemo na izlet. podrazumijeva i mogućnost da pada kiša i da ne idemo na izlet. Uporaba veznika si kao upitnoga veznika prema Hermanu (2000: 92-93) bila je rjeđe posvjedočena i u klasičnome latinskom, međutim postaje normalna i česta tek u kasnome latinskom, a odraz je toga vidljiv u romanskim jezicima. Herman smatra da je možda pojačana uporaba veznika si u prijevodu Biblije Vetus Latina pod utjecajem grčkoga jer je si služio kao istovrijednica grčkomu $\varepsilon i$ iako se naglašava da je takva mogućnost zabilježena još u Plauta. Zavisnoupitne rečenice s veznikom si

\footnotetext{
11 Gortan, Gorski i Pauš 2005: 279.

12 Neki su od primjera koje Pinkster navodi: Expecto si quid dicas. Pl. Trin. 98, Helvetii... nonnumquam interdiu, saepius noctu si perrumpere possent conati... hoc conatu destiterunt. Caes Gal. 1. 8. 4., Mirabar hoc si sic abiret, et eri semper lenitas verebar quorsum evaderet. Ter. An. 175 itd.

13 Touratier u svojoj sintaksi ističe dubitativnost takvoga si: ... car a subordonnée en si semble un peu plus dubitative que la subordonnée en quod. (Touratier 1994: 588).
} 
u značenju predikat + li prevode se doslovno veznicima ako i aĉe: ${ }^{14}$ ut probaret, si, ut Maria de Christo praedicaverat, sic veritas se haberet (De s. Maria Magdalena): iskusiti ako sutb istin'naê êže siê propovedaetb (CŽg 109r) / iskusiti istinu prop(o)v(ê)daniê Mar'tina ako su is'tinna (CIvan 115v); interrogabat autem si vere haec ita essent (2Mach 3,9): vprašaše že $\cdot$ ace vistinu siê bila bi (BrVO 425b). Rjeđe se međutim takav veznik si prevodi česticom li: Interrogate illam si est libera ut accipiam eam mihi uxorem, si ancillam, dabo pretium pro ea et erit mihi concubina (Lectio s. Margaritae): pitaite e eli slobod'na ali e raba ako e slob'dna vaz'mu $\hat{u}$ za ženu za lipotu nee ako li e raba dam' za nû cenu $i$ bude mi hot'nica (COxf 24d). U Mihaljević (2011a) ističe se da se u upitnim rečenicama uz percepcijske glagole kao veznička sredstva pojavljuju dopunjač $l i$, sveza jeda kako i pogodbeni veznici ace i ako. U primjerima u kojima se pojavljuju $a \hat{c} e$ i ako riječ je o slučajevima u kojima se ti veznici pojavljuju jer su formalni korespondenti latinskomu si. Međutim, o proširenosti uporabe veznika ako i aĉe u zavisnoupitnim rečenicama govori i činjenica da se on pojavljuje i u rečenicama u kojima nije potaknut latinskim si, npr. kao prijevod latinskoga utrum: scire cupientes utrum perseveraret in sententia (Est 3,4): vidêti želêuce aĉe prebival bi v dosudê $\left(\mathrm{BrN}_{2} 236 \mathrm{c}\right)$. Pojava veznika ako u upitnim rečenicama vjerojatno je potpomognuta i situacijom u talijanskome, u kojemu je to uobičajeni način uvođenja toga tipa zavisnoupitnih rečenica.

Konjunktiv prezenta u pravilu se prevodi prezentom: Qui habet aures audiendi audiat, quid Spiritus dicat ${ }_{\mathrm{SBJV} . \mathrm{PRS}}$ ecclesiis (Reg. s. Benedicti): ki imatb uši slišat, da slišit', ča d(u)hb govorit' ${ }_{\mathrm{PRS}} \operatorname{cr}(i) k v(a) m$ ' (RegBen 1v). Rjeđe se, međutim, prevodi kondicionalom: Quaerimus quis iste sit ${ }_{\text {SBJV.PRS }}$ Zacharias filius Barachiae (Hom. s. Hieronymi presb.): iĉêm že obak' kotori bil’ bi $i_{\mathrm{COND}} s b$ zahariê $\cdot s(i) n b$ varahiins (BrVO 46d).

Konjunktiv pluskvamperfekta uglavnom se prevodi pluskvamperfektom: Exposuit... et quanta eum gloria super omnes principes et servos suos rex elevasset $_{\mathrm{SBJV.PLPF}}$ (Est 5,11): isp(o)v(ê)dê... i kolikoû sl(a)voû ego · pače vsêhb vladikb $i$ rabb ego $\cdot c(\hat{e} s a) r b$ vzdvigalb be $\hat{e}_{\mathrm{PLPF}}(\mathrm{BrVO} 406 \mathrm{a})$.

S obzirom na to da je većina analiziranih tekstova u prošlome vremenu, u latinskim se zavisnim rečenicama najčešće pojavljuje konjunktiv imperfekta. Takav

14 O veznicima ašće i ako v. Mihaljević 1990. 
se konjunktiv imperfekta najčešće prevodi kondicionalom I. U tim se primjerima kondicionalom ne izriče potencijalnost, nego se kondicional pojavljuje kao istovrijednica latinskoga konjunktiva: scire volens quid ei accideret ${ }_{\text {SBJV.IMPERF }}$ (Est 2,11): $i$ vidêti hotê čto ei priklûčilo se bi $i_{\mathrm{COND}}(\mathrm{BrVO} 402 \mathrm{c})$.

\section{Izrične rečenice}

Izrične rečenice ne postoje kao vrsta u gramatikama klasičnoga latinskog jer se umjesto njih pojavljuju konstrukcije akuzativa ili nominativa s infinitivom. Međutim, u vulgarnome i srednjovjekovnome latinskom te se konstrukcije sve češće zamjenjuju zavisnim rečenicama (Herman 2000: 87), najčešće s veznikom quia $^{15}$, a rjeđe i veznikom quod, čije se značenje u kasnome latinskom također proširuje ${ }^{16}$. Katkad se u takvim rečenicama pojavljuju i veznici quoniam, quomodo i ut. Takve su zamjene osobito česte uz glagole govorenja i mišljenja (Cuzzolin 2013a: 51). Zbog toga se konstrukcije koje uvodi veznik quod često nazivaju i konstrukcijama dicere quod (Cuzzolin 2013b: 24). U izričnim rečenicama, osobito uz veznik quod, najčešće stoji indikativ. ${ }^{17} \mathrm{U}$ hrvatskome crkvenoslavenskom izrične se rečenice najčešće uvode veznicima êko i $d a .^{18}$

Rečenice s veznikom quia prevode se rečenicama s veznicima da, êko i ere. Veznik quia u latinskome je prototipni veznik uzročnih rečenica sa značenjem 'jer' i zato se kao njegov prijevod najčešće pojavljuje veznik êko, koji je čest veznik uzročnih rečenica u hrvatskome crkvenoslavenskom (Mihaljević 2016). Budući da je veznik quia prototipni veznik uzročnih rečenica, u izričnim rečenicama katkad se prevodi i veznikom ere: Et scias, quia nihil impium fecerim (Officium defunctorum): $i$ vij’' ere nič'ce nečisto stvorih' (CPar 198r).

\footnotetext{
15 Jedna je od značajka vulgarnoga i postklasičnoga latinskog činjenica da se smanjuje broj veznika kojima se uvode zavisne rečenice, tj. da se širi značenje pojedinih veznika. Osobito prisutni postaju veznici quia $\mathrm{i}$ quod. V. Herman 2000: 87 i Norberg 1968.

16 Pojava zamjene infinitivnih konstrukcija zavisnim rečenicama quia i quod pod utjecajem je i grčkih izričnih rečenica uvedenih veznikom ö $\tau$. Do pojačane uporabe tih veznika dolazi i zbog promjene u redu riječi (Herman 2000: 89).

17 O odnosu značenja rečenica s indikativom i konjunktivom uz pojedine izrične veznike v. Cuzzolin 1994: $60-74$.

18 The first group consists of clauses introduced by complementizers êko ([jako]), da, acelako, as well as different kinds of wh-interrogatives. (Mihaljević 2011b: 69). V. Gadžijeva i dr. 2014: 352.
} 
U korpusu je najveći broj izričnih rečenica s veznikom quod, koje su većinom prevedene veznikom $d a$. Rečenice s veznikom quod prevode se i rečenicama s veznikom êko. U primjeru Interpelavit et de sorore sua conquesta est, quod eam laborantem non adiuvaret (In assumptione BVM): gl(agola)še g(ospod)u ot sestri svoee tužaše se êk(o) ei truždaûci se ne pomagaše $\left(\mathrm{BrN}_{2} 468 \mathrm{~d} / 469 \mathrm{a}\right)$ pojavljuje se veznik quod, koji uvodi rečenicu kojom se izriče uzrok zbog kojega se sestra žali. Preveden je veznikom êko, a rečenica je vrlo bliska izričnoj rečenici. Kao veznik toga tipa izričnih rečenica pojavljuje se i izvorno odnosna zamjenica quod, koju prevoditelji katkad prevode doslovno odnosnim zamjenicama iže ili čto: Cumque de illis diceret, quod ignorarent eum (Hom. s. Augustini ep.): $i$ egda ot onêh' g(lago)laše iže ne znahu ego (BrVO 302d).

Kao veznici izričnih rečenica pojavljuju se i qualiter i quomodo, koji su prototipno prilozi sa značenjem 'kako'. Oni se prevode prototipnim formalnim korespondentom, prilogom kako: Mementote qualiter salvi facti sunt patres nostri in mari Rubro (1Mach 4,9): pomenête kako sp(a)seni biše oci naši v mori čr'mnêems (BrVO 416d).

U izričnim rečenicama u pravilu dolazi indikativ koji se prevodi doslovno, a rjeđe i konjunktiv. U Esteri nakon veznika quod glagol je u konjunktivu. Konjunktiv prezenta sustavno se prevodi prezentom: norunt provinciae, quod sive vir, sive mulier non vocatus, interius atrium regis intraverit, absque ulla cunctatione statim interficiatur ${ }_{\text {SBJv.PRS }}$ (Est 4,11): znaûtb vladan'ê da ili m(u)žb ili žena nezvanb v' vnutrni dvorb c(êsa)revb v'šal' bi bez' koterago pitan'ê da tadae da ubiet $_{\mathrm{PRS}}$ se $\left(\mathrm{BrN}_{2} 237 \mathrm{~b}\right)$. Konjunktiv perfekta prevodi se aoristom: Et scias, quia nihil impium fecerim ${ }_{\mathrm{SBJV.PERF}}$ (Officium defunctorum): $i$ vij’ ere ničce nečisto stvorih' $_{\text {AOR }}$ (CPar 198r), a pluskvamperfekta kondicionalom ili aoristom: Et renuntiatum est ... quoniam discessissent ${ }_{\mathrm{SBJV} . \mathrm{PLPF}}$ viri quidam, qui dissipaverunt mandatum regis, in loca occulta in deserto, et abiissent ${ }_{\mathrm{SBJV} . \mathrm{PLPF}}$ post illos multi (1Mach 2,31): i vzvêceno bê... da sašli bi $i_{\mathrm{COND}}$ muži eteri $\cdot$ iže razoriše povelênie $c(\hat{e} s a)$ revo $\cdot i$ otidu $v$ mêsta otainaê $v$ pustinû $\cdot i$ otidu $u_{\mathrm{AOR}}$ mnozi za nimi $(\mathrm{BrVO}$ 411c).

Konjunktiv imperfekta često se prevodi kondicionalom I., osobito u biblijskim tekstovima: et experimento probasset quod Mardochaeus non flecteret ${ }_{\text {SBJV.IM- }}$

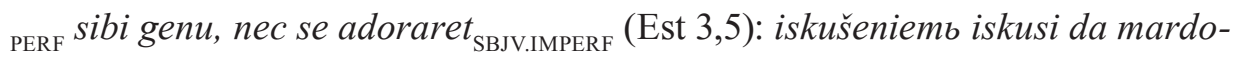
čei ne priklonil' bi $i_{\mathrm{COND}}$ kolêna ni emu poklonil bi $i_{\mathrm{COND}}$ se $\left(\mathrm{BrN}_{2} 236 \mathrm{c}\right)$, a rjeđe $\mathrm{i}$ 
prošlim vremenima. ${ }^{19} \mathrm{U}$ primjeru et cognovit quia moreretur ${ }_{\text {SBJV.IMPERF }}$ (1Mach 1,6): pozna êko umrêti $i_{\mathrm{INF}}$ imatb $_{\mathrm{PRS}}$ (BrVO 408a) konjunktiv imperfekta preveden je konstrukcijom imatb s infinitivom, kojom se izriče debitivno značenje.

\section{Namjerne rečenice}

U klasičnome latinskom radnja se namjerne surečenice smatra istodobnom s radnjom glavne surečenice, pa se u njoj pojavljuje konjunktiv prezenta ili imperfekta $^{20}$. Najčešći su veznici namjernih rečenica $u t$ (rjeđe $\left.u t i\right)$ i ne (rjeđe $u t n e^{21}$ ). Na hrvatski se crkvenoslavenski najčešće prevode namjernom rečenicom jer latinske i hrvatske crkvenoslavenske namjerne rečenice imaju vrlo sličnu strukturu. Najčešći su veznici te vrste rečenica u hrvatskome crkvenoslavenskom da i jako. ${ }^{22}$ Sveza ne forte prevodi se veznikom eda: et libera me de manibus impiorum et de manu carnificis, ne forte percussa formidet cor meum (Lectio s. Margaritae): iz'b(a)v(i) me ot ruki nečistivih' i ot ruki plto(u)biic' eda k(a)ko poražena ustrašit' se $\operatorname{sr}(\mathrm{b} d)$ ce moe (COxf 25b).

Namjerne se rečenice rjeđe prevode i drugim vrstama zavisnih rečenica koje mogu značenjski odgovarati kontekstu. Značenjski su najbliže namjernim rečenicama vremenska i posljedična rečenica: ut illic applicarent (De s. Maria Magdalena): i egda pristaše ka š’kolû (CŽg 110). U tome je primjeru prevoditelj vjerojatno prepoznao latinski veznik $u t$ kao vremenski veznik. Općenito je $u t$ uz cum najprošireniji veznik latinskih zavisnosloženih rečenica te stoga prevoditelji katkad pogrešno prepoznaju o kojemu je tipu rečenice riječ. Namjerna rečenica ut manifestius videret, illuc accessit (De s. Maria Magdalena) prevedena je kao vremenska, u Žgombićevu zborniku aktivnim participom preterita, a u Ivančićevu zborniku rečeničnim nizom: videvb pelegrin' detiĉa očito i tudie za nimb ka grobu pristupi (CŽg 111v) / očito otroče vidi · za nim' k' grobu pristupi (CIvan $117 \mathrm{v} / 118)$. Jedna je namjerna rečenica prevedena kao poredbena vjerojatno jer se

\footnotetext{
19 V. gore primjere iz $\mathrm{BrN}_{2} 468 \mathrm{~d} / 469 \mathrm{a}$ i BrVO 302d.

${ }^{20}$ Prema pravilima o slaganju vremena konjunktiv prezenta dolazi ako je u glavnoj rečenici glavno vrijeme - prezent, futur I., futur II. i imperativ; a konjunktiv prezenta dolazi ako je u glavnoj rečenici sporedno ili historijsko vrijeme - perfekt, imperfekt i pluskvamperfekt (v. Gortan, Gorski i Pauš 2005).

${ }^{21}$ Veznik ut non najčešće se upotrebljava da bi se naglasila niječnost ili zanijekao samo dio rečenice.

22 V. Gadžijeva 2014: 355-356.
} 
veznik ut pojavljuje i kao veznik poredbenih rečenica: suscepit eam ut nutriretur (Lectio s. Margaritae): lûblaše $\hat{u} k$ (a)ko da bi ot nee roena (COxf 24d).

Većina se konjunktiva, i kad je riječ o konjunktivu prezenta i kad je riječ o konjunktivu imperfekta, prevodi svršenim prezentom jer namjerne rečenice podrazumijevaju želju govornika da se neka radnja dovrši: aperi portas tuas, ut intret $_{\mathrm{SBJV.PRS}}$ rex gloriae (Ev. Nicod XXI): otvori vrata da vnidet $_{\mathrm{PRS}} c(\hat{e} s a) r b$ sl(a)-vi (FgNicod 1bc). Rjeđe se pojavljuje i prezent nesvršenih glagola: Maria ergo humeris eorum signum crucis imposuit, ne eos antiquus hostis in aliquo itinere impediret $_{\mathrm{SBJV.IMPERF}}$ (De s. Maria Magdalena): mariê že na ramenu ê̂ znamenie križa $<$ p >oloži da dêvalb imb ne pakostuetb ${ }_{\mathrm{PRS}}$ puti b(o)žiê (CŽg 109v).

U primjeru Et post sex mensuum circulum legatur ei regula, ut sciat ${ }_{\mathrm{SBJV} . \mathrm{PRS}}$ ad quod ingreditur (Regula s. Benedicti): i na konacb šestoga miseca · čti mu se na opetb taje regula $\cdot d a v i \hat{j}_{\mathrm{IMP}}$ na čb vlize (RegBen $38 \mathrm{~b}$ ) konjunktiv je prezenta preveden imperativom. Riječ je o glagolskome obliku vijhb, koji je vrlo čest, pa je moguće da se zbog toga pojavljuje u prijevodu. U nekim je značenjima konjunktiv vrlo blizak imperativu (npr. jusivni konjunktiv u nezavisnim rečenicama), stoga je moguće i da prevoditelj uporabom imperativa pokušava vjerno oponašati izvornik.

Jednom je konjunktiv prezenta preveden perifrastičnim oblikom futura bude + infinitiv (Kravar 1978): et dedit Adae et ostendit ei laborare et colere terram,

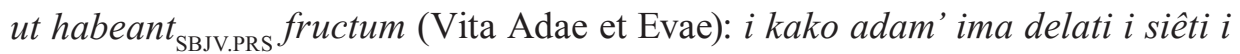
težati zemlju da b(u)de PRS $_{\text {imeti }}$ plod'b $_{\text {INF }}$ (Č̌g 34v/35r). ${ }^{23}$

Dio je konjunktiva u namjernim rečenicama, osobito konjunktiva imperfekta, preveden kondicionalom I.: Ego quidem misi fratrem meum Rufonem ... ut absorberet $_{\text {SBJV.IMPERF }}$ et tolleret $_{\text {SBJV.IMPERF }} \cdots$ et obrueret $_{\text {SBJV.IMPERF }}$ virginitatem tuam (Lectio s. Margaritae): a ê poslah' rufena brata moego ... da pogubil' biCOND dev'stvo tvoe (COxf 26c). Tu nije riječ o isključivome latinskom utjecaju jer se kondicional općenito može pojaviti u namjernim rečenicama.

\footnotetext{
${ }^{23}$ Futur I. u hrvatskome se crkvenoslavenskom tvorio s pomoću prezenta glagola hotêti, načeti, imêt $i$, včet $i$ i počet $i$ infinitiva, ali se pod utjecajem govornoga jezika pojavaljuje i tvorba s trenutnim prezentom glagola biti i infinitivom (npr. piti budu) (Gadžijeva i dr. 2014: 255).
} 


\section{Zahtjevne rečenice}

Zahtjevne rečenice $u$ latinskim se gramatikama najčešće nazivaju rečenicama uz verba postulandi i curandi te su bliske namjernim rečenicama. U njima uvijek stoji konjunktiv prezenta ili imperfekta prema pravilima o slaganju vremena za istovremenost. U Gadžijeva i dr. (2014: 352) takve se rečenice djelomično opisuju među finalnim rečenicama, a djelomično među željnima. Veznik $u t$ prevodi se veznikom $d a$.

Konjunktiv prezenta prevodi se prezentom: Quid ergo vis ut faciam SBJv.PRS $_{\text {(In }}$ conceptione $\mathrm{BMV})$ : čto hoĉeši da st'voru ${ }_{\mathrm{PRS}}\left(\mathrm{BrN}_{2} 388 \mathrm{a}\right)$, a konjunktiv imperfekta uglavnom kondicionalom I.: mandavit illis ut essent ${ }_{\text {SBJV.IMPERF }}$ parati (1Mach 3,28): pov(e)lê imb da bili bi ${ }_{\text {COND }}$ gotovi k' vsêmb ( BrVat $\left._{5} 222 \mathrm{~d}\right)$.

Zanimljiv je primjer Et misit rex libros per manus nuntiorum in Jerusalem, et in omnes civitates Juda, ut sequerentur $r_{\mathrm{SBJVIMPERF}}$ leges gentium terrae, et prohiberent $_{\mathrm{SBJV.IMPERF}}$ holocausta et sacrificia, et placationes fieri in templo Dei, et prohiberent $_{\text {SBJV.IMPERF }}$ celebrari sabbatum, et dies solemnes (1Mach 1,46-49): i posla c(êsa)rb anbtiohb knigi posalb rukami ka iz(drai)lemb $\cdot i$ vb vse gradi iûdovi - da naslêdovali bi $i_{\mathrm{COND}}$ zakonb êzikb z(e)ml(b)skihb $\cdot i_{\text {otvrbgutb }}$ otRS $_{\text {olokavti } i}$ žr'tvi · i ugodie bratie (sic!) · v cr(b)kvi b(o)ži da otvr'gutb ${ }_{\mathrm{PRS}}$ čisti sobotu i d(b)ni prazdnikb (BrVO 409c), u kojemu je prvi konjunktiv preveden kondicionalom, a koordinirani glagoli prezentom. Uporaba kondicionala u tim je rečenicama vjerojatno rezultat latinskoga utjecaja.

Konjunktiv imperfekta rjeđe se prevodi i prezentom: cum Salomon petiit ut locus sanctificaretur ${ }_{\text {SBJV.IMPERF }}$ magno Deo (2Mach 2,8): egda solomunb prosi da mêsto $s$ (ve)tit $t_{\mathrm{PRS}}$ se $\cdot$ velikomu b(og)u (BrVO $\left.423 \mathrm{~cd}\right)$. Zahtjevnost se rečenice katkad u prijevodu izriče i infinitivom: Factum est autem decretum ut... describerentur $_{\text {SBJV.IMPERF }}$ (Protoevangelium Jacobi): izide povelênie ot avgusta kesara napisati $_{\mathrm{INF}}$ se vsei vselenêi $\left(\mathrm{BrBer}_{2} 28 \mathrm{c}\right)$.

\section{Vremenske rečenice}

U latinskim vremenskim rečenicama može stajati i indikativ i konjunktiv, ovisno o vezniku te o odnosu glavne i zavisne rečenice. Najčešći je veznik cum, koji 
se pojavljuje u dvjema inačicama kao cum temporale i cum historicum ili narrativum. Osim veznika cum u vremenskim se rečenicama može pojaviti i jedan od najproširenijih veznika u zavisnim rečenicama $u t$ te mnogi drugi veznici. $\mathrm{U}$ hrvatskome crkvenoslavenskom najčešći je veznik vremenskih rečenica veznik egda, ali je u hrvatskoglagoljskim tekstovima čest i hrvatski veznik kada. ${ }^{24}$

U korpusu je najčešći veznik cum historicum ili narrativum, koji stoji kad je riječ o prošlim događajima. Uz takav cum uvijek stoji konjunktiv imperfekta ili pluskvamperfekta prema pravilima o slaganju vremena. Konjunktiv imperfekta nakon toga veznika uglavnom se prevodi jednostavnim prošlim vremenima aoristom i imperfektom: cum adhuc viveret ${ }_{\text {SBJVIMPERF }}$ (1Mach 1,7): egda oĉe živb bêše ${ }_{\text {IMPERF }}$ (BrVO 408a). U primjeru Nam cum in Perside esset dux ipse, et cum ipso immensus exercitus, cecidit in templo Naneae, consilio deceptus sacerdotum Naneae. (2Mach 1,13): êko egda v per'sidê bêše mužb · i egda s' besčisl'nimi voi vpade v crêk(b)vb svêtomb nanêe etera ulaĉens (BrVO 422ab) prevoditelj udvaja veznik egda vjerojatno potaknut latinskim prijedlogom cum, koji je homoniman s veznikom.

Konjunktiv pluskvamperfekta često se prevodi aoristom: Quae cum audisset ${ }_{\mathrm{SBJV}}$. ${ }_{\mathrm{PLPF}}$, turbata est in sermone eius (Officium b. Mariae in adventu): ka gda sliša $a_{\mathrm{AOR}}$ smete se o sl(o)vesi ego (CPar 192v). U primjeru Cumque proposuissent ${ }_{\mathrm{SBJV} \text {.PLPF }}$ eas sacerdotes Naneae, et ipse cum paucis ingressus esset ${ }_{\mathrm{SBJV} . \mathrm{PLPF}}$ intra ambitum fani, clauserunt templum, cum intrasset $t_{\text {SBJv.PLPF }}$ Antiochus (2Mach 1,15): i egda prêdložiš $e_{\mathrm{AOR}}$ e erêi ot nanêê $\cdot i$ s rêtkimi všalb bêše ${ }_{\mathrm{PLPF}}$ vnutarb $\cdot v$ pritvorb crêkve $\cdot i$ zatvoriše cr(ê) $k(b) v b \cdot i$ egda všadb ${ }_{\mathrm{PP}}$ an’tiohb (BrVO 422b) tri su koordinirana glagola uz veznik cum. Prvi je konjunktiv pluskvamperfekta preveden aoristom, drugi pluskvamperfektom svršenoga glagola, a treći participom prošlim. Vjerojatno je riječ o želji prevoditelja da variranjem smanji monotonost teksta. U biblijskim se tekstovima konjunktiv pluskvamperfekta najčešće prevodi pluskvamperfektom svršenoga glagola jer prevoditelji biblijskih tekstova

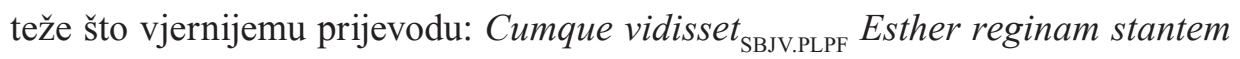

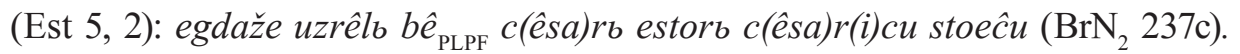
$\mathrm{U}$ primjeru Qui cum reversus esset ${ }_{\mathrm{SBJV} . \mathrm{PLPF}}$ de horto nemoribus consito, et intrasset $_{\mathrm{SBJV.PLPF}}$ convivii locum, reperit Aman super lectulum corruisse (Est 7,8): iže egda vzvratil' se bi $i_{\mathrm{COND} / \mathrm{PLPF}}$ ot vrta dubravami sbstavlenago $\cdot i$ všalb b $\hat{e}_{\mathrm{PLPF}} v$

\footnotetext{
24 V. Gadžijeva i dr. 2014: 353. O vremenskim rečenicama pisala je i Kovačević 2016.
} 
braka mêsto · v'z'obrete amana na postelu spad'ša $\left(\mathrm{BrN}_{2} 238 \mathrm{c}\right)$ drugi je glagol preveden pluskvamperfektom, a za prvi je teško odrediti je li riječ o kondicionalu ili pluskvamperfektu, zbog glasovne bliskosti tih dvaju oblika. Moguće je da je riječ o ikavskome odrazu jata ili o prepisivačevoj pogrešci.

Vremenska se rečenica s cum historicum katkad prevodi i participskim konstrukcijama s veznikom ili bez njega. U primjeru cum vidisset eum Eva flentem (Vita Adae et Evae): i kada videv' ga euga plačuĉa se (CŽg 37v) uz particip se

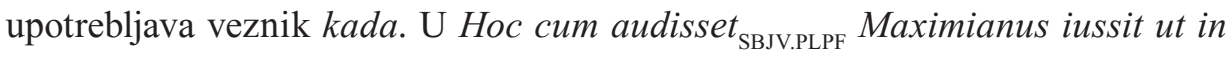
custodia ipsi foderent harenam (In festo s. Marcelli papae): egda že sie slišavb $b_{\mathrm{PP}}$ mak'simiên a v'gus'ts povelê da si v' straži rîutb pržinu $\left(\mathrm{BrN}_{2} 393 \mathrm{c}\right)$ konjunktiv pluskvamperfekta preveden je participom prošlim uz veznik egda. U Haec cum audisset $_{\text {SBJv.PLPF }}$ Eva cognovit quod diabolus suasit exire de flumine (Vita Adae et Evae): slišav ${ }_{\mathrm{PP}} \check{z}$ e sie euga da dêvl' est' ki û čini iziti iz vodi (CŽg 32v) i cum

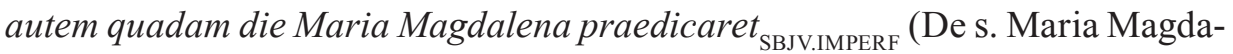
lena): pripovidâिc $\hat{i}_{\mathrm{PRESP}}$ že b(la)ž(e)na mariê magdalena (CŽg 108v) konjunktivi su prevedeni participima bez veznika. Prevođenje veznika uz particip odražava težnju prevoditelja da svaku riječ u tekstu doista i prevede. U primjeru cum ergo transiisset $_{\text {SBJV.PLPF }}\left(\right.$ De s. Patricio): i potom' malo prešad ${ }_{\text {PP }}($ COxf 48a) veznik cum preveden je prilogom potom, a glagol participom.

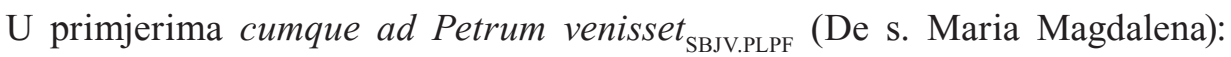

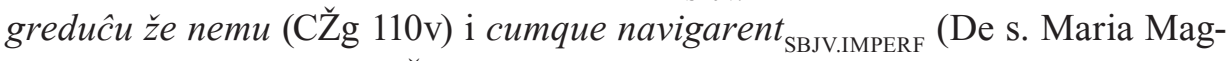
dalena): i iduĉimb nimb (CŽg 111r) vremenska se rečenica prevodi dativom apsolutnim. Pojava dativa apsolutnoga u primjerima u kojima ne zamjenjuje latinski ablativ apsolutni iznimno je važna za dataciju prijevoda jer nakon 13. stoljeća dativ apsolutni više nije živa konstrukcija. ${ }^{25}$

Pod latinskim se utjecajem i u vremenskim rečenicama katkad kao istovrijednica latinskoga konjunktiva imperfekta i pluskvamperfekta pojavljuje kondicional. Svi su primjeri iz biblijskih tekstova i u svima je veznik egda: Cumque

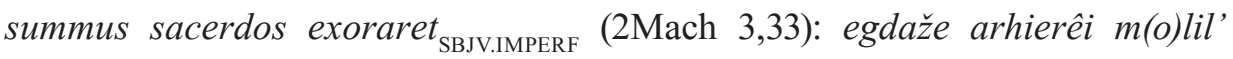
$b i_{\text {COND }}$ onêžde ûnoši $(\mathrm{BrVO} 426 \mathrm{c})$, cum suscepisset ${ }_{\mathrm{SBJV} . \mathrm{PLPF}}$ regnum Antiochus (2Mach 4,7): egda priêl' bi ${ }_{\mathrm{COND}}$ c(êsa)rstviê an'tiohb (BrVO 427b). U primjeru

\footnotetext{
${ }^{25}$ In the practice the Dativus absolutus must have been still familiar to the translators of the prayers of the mass - their translation is commonly dated to the 13. cent. (...) the absolute dative was obsolete in the 14. cent. (Mihaljević i Reinhart 2005: 67). O dataciji teksta v. A. Mihaljević 2014.
} 


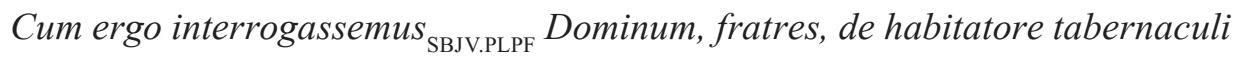
eius (Reg. s. Benedicti): ûre br(a)t(i)ê, uprosimo ${ }_{\mathrm{IMP}} g$ (ospod) a prêbivatela v žilicî ego (RegBen 3r) vremenska je rečenica s cum historicum i konjunktivom pluskvamperfekta prevedena imperativom bez veznika. Prevoditelj se na to odlučio vjerojatno zbog vokativa koji označava izravno obraćanje kakvo je svojstveno imperativnim rečenica.

Rjeđe se veznik cum pojavljuje i s konjunktivom prezenta i perfekta. Oba se oblika prevode prezentom, a veznik cum veznikom egda (gda): Cum ad omnium sanctorum reverentiam christianorum cunctorum debeat ${ }_{\mathrm{SBJV} . \mathrm{PRS}}$ devotio excitari ad beatae mariae semper virginis laudem, et praeconia extollenda (In festo s. Mariae ad nives): g'da k'vsêh's(ve)tih' časti hr(st)ênov' vsih' imat ${ }_{\mathrm{PRS}}$ se bogolûbie vz'buditi k' b(la)ž(e)nie m(a)rie vsbgda d(ê)vi $h v(a) l i$ i propovêdaniû v'znašaemu (CPar 167r); Cum immundus spiritus exierit SBJv.PERF $_{\text {ab homine, }}$ ambulat per loca inaquosa (Ant.): egda nečisti d(u)h' izidet' ${ }_{\mathrm{PRS}}$ ot č (lovê)ka prêhodit'skvozê bezvodnaê mêsta (BrVO 187c).

Veznik dum u pravilu se prevodi veznicima kada ili egda, rjeđe veznikom dokolê, a iznimno i drugim veznicima kao što su dari i ere. Uz veznik dum konjunktiv imperfekta najčešće se prevodi aoristom ili imperfektom: quos dum ille audire contemneret $t_{\mathrm{SBJVIIMPRF}}$ (De s. Patricio): $i$ kada li ne hot ${ }_{\mathrm{AOR}}$ po nih' voli učiniti (COxf 47d-48a). U primjeru dum absentes essent SBJV.IMPERF $_{\text {angeli (Vita }}$ Adae et Evae): kada odstupili behu $u_{\mathrm{PLPF}}$ an'j(e)li (CŽg 37v) konjunktiv je preveden pluskvamperfektom, vjerojatno kako bi se vjerno prenijela latinska struktura u kojoj je particip prezenta uz konjunktiv imperfekta glagola biti, a hrvatski crkvenoslavenski pluskvamperfekt također se sastoji od participa i imperfekta glagola biti. Konjunktiv prezenta prevodi se aoristom: Hoc perficiant, usque dum benedicat $_{\text {SBJV.PRS }}$ et dicat $t_{\mathrm{SBJV.PRS}}$ (Reg. s. Benedicti): to vs(e)gda činite dari opatb reče ${ }_{\mathrm{AOR}}$ (RegBen 30r) ili prezentom: ut per ordinationem praepositi scandala gravia in monasteriis oriantur, dum sint $t_{\mathrm{SBJV} . \mathrm{PRS}}$ aliqui maligno spiritu superbiae inflati (Reg. s. Benedicti): da ere skozi narejenie pripuĉ'ta v manastirihb mnogo hudobê obrêcet se · ere budu $u_{\mathrm{PRS}}$ niki z(a) limb d(u)homb i gizdavimb nadmeni (RegBen 45a). U prvome se primjeru veznik dum prevodi veznikom dari, a u drugome veznikom ere, vjerojatno jer je taj veznik već upotrijebljen u rečenici. U primjeru Dum egressus fuerit ${ }_{\mathrm{SBJV} . \mathrm{PERF}}$ de aqua Jordanis, tunc de deo misericordiae suae perunguet omnes credentes in se (Vita Adae et Evae): i kogda 
izidet' ${ }_{\mathrm{PRS}}$ iz' vodi tada oleem' milosrdiê pomažet' vsih' vêruûcih' v nega (CŽg $38 \mathrm{v}$ ) veznik dum uz konjunktiv perfekta prevodi se veznikom kogda, a glagol je preveden prezentom.

Uz veznik donec, preveden veznikom dokole, konjunktiv prezenta prevodi se svršenim prezentom: et lugebo omni hora, donec in infernum descendam SBJV. $_{\text {. }}$ PRS ad te, fili mi (Lectio de Josepho): i sêtû́ po vse časi doklê snidu $u_{\mathrm{PRS}} v^{\prime}$ ad' $k$ tebi sinu moi (COxf 18c). Uz taj se veznik pojavljuje i konjunktiv imperfekta

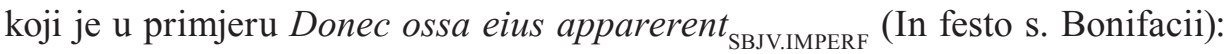
dokle kosti ego êvet ${ }_{\mathrm{PRS}}$ se $\left(\right.$ BrVat $\left._{6} 109 \mathrm{~d}\right)$ preveden svršenim prezentom, u Tunc iratus profectus iussit beatissimam Margaritam in carcerem recludi, donec inveniret $_{\text {SBJV.IMPERF }}$ per qualem machinationem eius virgiitatem perderet. (Lectio s. Margaritae): tada zapovida kral' b(la)ž(e)nu margaritu v tam'nici zatvoriti $i$ dokle iz'našal' ${ }_{\text {COND }}$ koeû hitrostiû dev'stvo nee pogubil' bi (COxf 25a) kondicionalom, a u quod nemo ex eis cecidisset donec reverterentur $r_{\text {SBJVIMPERF }}$ in pace (1Mach 5,54): êko niktože iz' nihb palb bê $\cdot$ doideže vratiše ${ }_{\mathrm{AOR}}$ se v miru (BrVO 421a) aoristom.

Vremenski veznik $u t \mathrm{u}$ pravilu stoji uz indikativ i obično se prevodi veznicima kada ili egda. Zbog višefunkcionalnosti veznika ut pri njegovu prevođenju česte su nedoumice i pogreške jer prevoditelji ne prepoznaju vrstu rečenice. U primjeru ut ita fuissent .... separati ${ }_{\mathrm{SBJV} . \mathrm{PLPF}}$ (Vita Adae et Evae): $i$ kada besta razlučena $a_{\mathrm{PLPF}}$ (CŽg 35r) veznik je potvrđen uz pasivni konjunktiv pluskvamperfekta koji je preveden pluskvamperfektom. Veznik ut prevodi se i veznikom êkože, koji najčešće nije vremenski veznik, ali ima širok spektar značenja: Ut cessavit autem loqui, insiluit in eos subito (1Mach 3,23): êkože prêstaše g(lagol)ati $\cdot$ naskoči na ne vnezapu (BrVO 415a). Jedno je od češćih značenja i veznika $u t$ i veznika êkože poredbeno, a veznik êkože često je i uzročni veznik. Možda je u takvim primjerima riječ o nedoumici prevoditelja oko toga o kojoj je vrsti rečenice riječ i zbog bliskosti poredbenoga, uzročnoga i vremenskoga značenja.

U biblijskim se tekstovima veznik postquam prevodi veznikom poneže, koji oponaša strukturu latinskoga veznika jer se post najčešće prevodi prijedlogom po, a odnosna je zamjenica quam prevedena odnosnim neže: ${ }^{26}$ Dixitque ei rex, postquam vinum biberat abundanter (Est 5,6): r(e)če že ei c(êsa)rb poneže vino

\footnotetext{
26 V. Etymologický 2002: 682.
} 


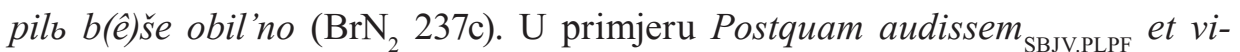
dissem $_{\text {SBJv.PLPF, }}$ cecidi ut adorarem ante pedes angeli (Ant.): egdaže slišah' ${ }_{\mathrm{AOR}} i$ vidêh' ${ }_{\mathrm{AOR}}$ 'pad' pokloniti se prêd' nogama ego · anĵ(e)lb (BrVO 269b) konjunktiv je pluskvamperfekta preveden aoristom. U Postquam autem resurrexero ${ }_{\mathrm{FUTI}}$, praecedam vos in Galilaeam (Ant.): potomžde egda vskrbsnu $u_{\mathrm{PRS}} \cdot$ prêd'idu vi v galilêi (BrVO 225v) veznik postquam prevodi se svezom potomžde egda. Futur II. preveden je svršenim prezentom.

Veznik quamdiu prevodi se kalkom eliko dlgo: Et tamdiu imminens naufragium perseverat: quamdiu Jesus veniat ${ }_{\mathrm{SBJV} . \mathrm{PRS}}$ (Hom. s. Hieronymi presb.): i toliko dlgo trpêse valaûci se · eliko dlgo is(us)b pride ${ }_{\mathrm{AOR}}$ k nimb (BrBer $_{1}$ 81d) koji je povezan s korelativom tamdiu prevedenim s toliko dlgo. Konjunktiv prezenta preveden je aoristom.

Veznik antequam prevodi se svezom pree neže, čime se vjerojatno također oponaša latinski predložak jer je prijedlog pree jedan od načina prevođenja prijedloga ante, a neže odgovara quam. ${ }^{27} \mathrm{U}$ primjeru Biennio itaque, antequam spiritum

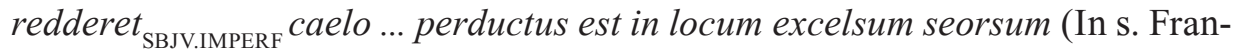
cisci): d'vê ubo lêtê · preje neže vzdal bi $i_{\mathrm{COND}} d(u) h_{b} \cdot n a b(o g) u$... vodeĉ' se po trudêhb mnozêhb dovedens bê v mêsto visokoe na vrhs (BrVat $\left.{ }_{6} 188 \mathrm{c}\right)$ konjunktiv imperfekta preveden je kondicionalom, a u ut benedicam eos, antequam moriar $_{\text {SBJv.PRS }}$ et loquar cum eis (Vita Adae et Evae): da govoru š nimi i b(lagoslov)lû i pree neže umru ${ }_{\mathrm{PRS}}(\mathrm{CŽg} 36 \mathrm{v}-37 \mathrm{r})$ konjunktiv prezenta prezentom.

Veznik usquequo prevodi se veznikom dondeže. U primjeru usquequo consumptum esset SBJV.PLPF sacrificium $_{\text {(2Mach 1,30): dondeže svršit }}$ sRS šr'tva (BrVO 423a) pojavljuje se konjunktiv pluskvamperfekta pasivnoga koji se prevodi prezentom.

\section{Uzročne rečenice}

Uzročne se rečenice u latinskome najčešće uvode veznicima quia, quoniam, quando, siquidem i quandoquidem $\mathrm{s}$ indikativom, veznikom quod s indikativom i konjunktivom i veznikom cum (cum causale) s konjunktivom. U analiziranome su korpusu najčešće potvrđeni veznici quia i cum. I jedan i drugi vrlo su česti

\footnotetext{
27 Etimologija je toga neže drukčija od onoga u svezi poneže. V. Etymologický 1999: 543.
} 
veznici koji uvode i druge vrste rečenica. Veznik quia u postklasičnim tekstovima često uvodi izričnu rečenicu, a veznik cum najčešći je veznik vremenskih rečenica, ali može imati i dopusno značenje. S obzirom na semantičku bliskost latinskih rečenica s cum historicum is cum causale autori tekstova katkad griješe pri prevođenju uzročnih rečenica te ih prevode kao da je riječ o vremenskim rečenicama. U službi uzročnih se veznika u hrvatskome crkvenoslavenskom pojavljuju veznici jako, zańe, zańe jako, togo radi, togo radi jako, zač (Gadžijeva i dr. 2014: 355), are, da, eda, ereler'/eže, poneže, zakai. Mnogi od tih veznika mogu uvoditi i druge rečenice osim uzročnih (Mihaljević 2016).

Svi su primjeri u korpusu u kojima se pojavljuje veznik ere prijevod latinskoga veznika quia: Et abstuli ab oculis vestris propter peccata vestra, quia non custodistis diem sanctum dominicum (Epistola de caelo missa): $i$ vbzmu e otb očiû vašêu skozê grêhi vaše · eže vi ne strêgoste d(b)ne moego s(ve)tie ned(ê)l(e) (FgEpist 1r).

U korpusu se uzročni veznik cum pojavljuje mnogo rjeđe od veznika quia, a u prijevodu se često zamjenjuje s vremenskim veznikom cum: Et cum esset ipsa occupata in cura ministrandi, soror eius Maria sedebat ad pedes Domini (Hom. s. Augustini ep.): $i$ egda biše siê održana pečaliû v službê sestra ee imenemb m(a)riê sêdêše pri nogu g(ospod)niûu ( $\left.\mathrm{BrN}_{2} 468 \mathrm{~d}\right)$.

U tekstu Život Marije Magdalene raspodjela je veznika ere i začb/zane ovisna o latinskome izvorniku. Veznik cum u Ivančićevu zborniku prevodi se veznikom začb, a u Žgombićevu veznikom zane, a veznik quia veznikom ere. U primjeru cum tot divitiis abundetis $s_{\text {SBJV.PRS }}$ (De s. Maria Magdalena): začb v' tolici bog(a)t(b)stvi pr(ê)bivaûce $e_{\mathrm{PRESP}}$ (CIvan 114v) konjunktiv prezenta preveden je participom. U primjerima etenim cum sis SBJV.PRS $_{\text {gravida et in mari sint }}$ SBJV.PRS $_{\text {infinita }}$ pericula (De s. Maria Magdalena): zane priseb'na ti esi $i_{\mathrm{PRS}} \cdot i$ nest $<t>i$ lepo iti

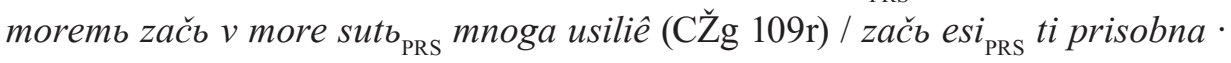
a v' mori mn(o)ga usil'ê (CIvan 115v) i cum non sit ${ }_{\mathrm{SBJV.PRS}}$ (De s. Maria Magdalena): zane nestb ${ }_{\text {PRS }}\left(\mathrm{CŽg} \mathrm{110v)} \mathrm{/} \mathrm{zač'} \mathrm{nis'tb}{ }_{\text {PRS }}\right.$ (CIvan 117r) konjunktiv prezenta preveden je prezentom, a u cum non sit ${ }_{\mathrm{SBJV} . \mathrm{PRS}}$ (De s. Maria Magdalena): zane ne $b e_{\mathrm{AOR}}\left(\mathrm{CŽg} \mathrm{109v)} \mathrm{/} \mathrm{začb} \mathrm{ne} \mathrm{bi} i_{\mathrm{AOR}}\right.$ (CIvan 116r) aoristom. Primjer cum tot divitiis abundetis (De s. Maria Magdalena): počto v tolicê bogatastve prebivâ̂ce (CŽg 108r) u Žgombićevu zborniku preveden je s veznikom počto. 


\section{Dopusne rečenice}

Latinske dopusne rečenice uvode veznici quamquam, etsi, tametsi i etiamsi, koji dolaze s indikativom, te veznici quamvis, licet, ut, ut non ili ne i cum s konjunktivom, prema pravilima o slaganju vremena. U hrvatskome crkvenoslavenskom dopusne se rečenice uvode svezama aĉe $i$ i ako $i$ te je povezanost između dopusnih i pogodbenih rečenica vidljiva i u izboru veznika. ${ }^{28}$

Dopusne se rečenice u analiziranome korpusu najčešće pojavljuju u Esteri, uvedene su veznikom etiamsi koji se prevodi s pomoću oĉe aĉe ili oĉe ako. Te sveze i formalno odgovaraju složenomu latinskom vezniku etiamsi jer je drugi dio veznik $s i$, čija je istovrijednica veznik ace, odnosno ako. Etiam je konektor sa značenjem 'i također', 'dapače', 'upravo' te se doslovno prevodi česticom oĉe sa značenjem ' još: etiam si dimidiam partem regni petieris, dabitur tibi (Est 5,3): oce ace polovnuû čestb c(êsa)rstviê moego prosila budešb dast' se tebê (BrVO 405d).

U Drugoj knjizi o Makabejcima veznik etiamsi preveden je svezom takožde aĉe:

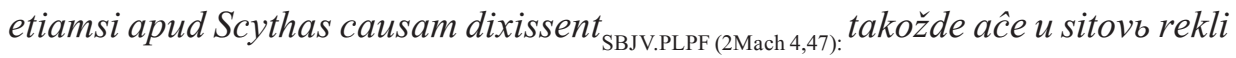
$b i_{\text {COND }}($ BrVO 429b). Riječi takožde i oĉe bliskoga su značenja, pa ne iznenađuje njihova izmjenična uporaba. Glagol je u tome primjeru u konjunktivu pluskvamperfekta koji se prevodi kondicionalom. Konjunktiv prezenta prevodi se prezentom: Etiamsi a quovis rogetur ${ }_{\mathrm{SBJv} . \mathrm{PRS}}$, nisi forte ei ab abbate suo praecipiatur.

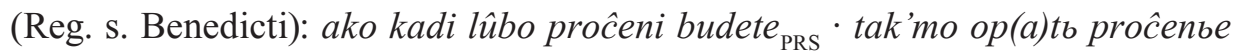
vzdalb budet' (RegBen 33v).

U korpusu su rečenice s dopusnim cum (cum concessivum) vrlo rijetke jer je riječ o vezniku koji autori i prevoditelji prototipno doživljavaju kao vremenski veznik. Zbog toga pri izricanju dopusnosti prevladavaju drugi veznici. Dopusni je veznik cum, međutim, hrvatski prevoditelj preveo s egda, koji je prijevodna istovrijednica vremenskoga cum te je rečenica pogrešno prevedena vremenskom rečenicom: etiam cum senuerit ${ }_{\mathrm{SBJV} . \mathrm{PERF}}$ non recedebat ab ea (In s. Dominici conf.): oce egda sbstara ${ }_{\mathrm{AOR}}$ ne otstupi ot nego $\left(\mathrm{BrN}_{2} 459 \mathrm{~b}\right)$. Dopusnost je u latinskoj rečenici izražena konjunktivom perfekta, koji se u pravilu ne upotrebljava u vremenskim rečenicama s cum, ali ga autor prevodi aoristom, koji je očekivano vrijeme u rečenici s cum historicum.

28 V. Gadžijeva i dr. 2014: 356. 
Dopusni veznik etsi prevodi se svezom $i$ aĉe, koja je tipična za dopusne rečenice u hrvatskome crkvenoslavenskom, a i oblikom odgovara latinskomu vezniku jer se sastoji od et ('i') i si ('ako'): qui etsi interna ac mystica penetrare nesciunt, pro intentione tamen supernae patriae docent recta quos possunt (Hom. s. Gregorii papae): iže i aĉe vnutrn'nimi prêhaždati ne videtb · na pro nastavu višnago otčbstva učets prava eliko mogutb $\left(\mathrm{BrN}_{2} 341 \mathrm{~b}\right)$.

U rečenici Quamvis etsi illas solas intelligeremus, quae Sanctimoniales vocantur (Sermo s. Augustini ep.): êko aĉe bi lê one same razumêemb · eže s(ve)te koludrice imenuût' se ( $\left.\mathrm{BrN}_{2} 349 \mathrm{~b}\right)$ pojavljuje se kombinacija dopusnih veznika quamvis i etsi, što se prevodi kao êko ace bi lê. U quemquam falsum iudicans ammodo non laedes est pro te nunc misera in inferno sedes. (Visio Philiberti): $t i$ v'živote krivo suêše. a hoĉb samb biti zlo osuen' (COxf 8a) dopusna je rečenica uvedena veznikom quamquam (pisano quemquam), a na hrvatski crkvenoslavenski prevedena je kao nezavisna rečenica nakon koje slijedi suprotna rečenica $\mathrm{s}$ veznikom a. U Latere tamen non potuit ... quamquam manus quasi semper portaret contectas et pedibus ex tunc incederet calceatis. (In s. Francisci): na obače taiti ne vzmože ... r(u)cê že v'sagda nose pokr'veni i nogami ottolê hoêše obuvenimi (BrVat ${ }_{6}$ 190a) dopusna rečenica s veznikom quamquam također se ne prevodi doslovno. Na mjestu veznika quamquam stoji čestica že, a rečenica je prevedena kao glavna.

Dopusne rečenice s veznikom quamvis također se prevode svezom aĉe $i$ : quamvis esset $t_{\mathrm{SBJVIIMPRF}}$ ei suspectus (2Mach 4,34): ace $i$ bil bi $i_{\mathrm{COND}}$ emu pod'zoritb (BrVO 428d). Konjunktiv je imperfekta preveden kondicionalom I.

Veznik je licet oblikom bezlični glagol koji u dopusnim rečenicama dobiva vezničko značenje. Međutim, prevoditelji ga ne prepoznaju kao dopusni veznik i prevode ga glagolom: Nam licet Hieronymus sex milia volumina Origenis se legisse fateatur, iste tamen tanta scripsit. (Vita s. Augustini ep.): možetb biti êk(o) eronimb šestb tisuĉi knigb or'ena čisti se suĉi povêda $\cdot$ da si toliko pisa $\left(\mathrm{BrN}_{2} 372 \mathrm{a}\right)$.

\section{Posljedične rečenice}

Posljedične rečenice u latinskome se uvode veznicima ut, quin i ut non. U njima u pravilu uvijek stoji konjunktiv i to apsolutno, tj. ne slijedi pravila o slaganju 
vremena, nego se upotrebljava konjunktiv onoga vremena koje bi stajalo da je riječ o jednostavnoj rečenici. U hrvatskome crkvenoslavenskom uvode se veznicima da, jako, jako da i tako jako (Gadžijeva i dr. 2014: 355). U analiziranome korpusu pojavljuju se vrlo rijetko.

Konjunktiv prezenta prevodi se prezentom: De Abel nulla est ambiguitas, quin is sit ${ }_{\mathrm{SBJV} . \mathrm{PRS}}$ quem Cayin frater occiderit (Hom. s. Hieronymi presb.): o abele nikoeže est' raspačanie sb bo est' ${ }_{\mathrm{PRS}} v$ istinu · onb egože kaenb brat' ubi (BrVO 46c-46d). U primjeru Sed miracula Domini et Salvatoris nostri sic accipienda sunt, fratres carissimi, ut et in veritate credantur ${ }_{\mathrm{SBJV} . \mathrm{PRS}}$ facta et tamen per significatione nobis aliquid innuant $_{\mathrm{SBJV.PRS}}$ (Hom. s. Gregorii papae): nb čudesa g(ospod)a $n(a) \check{s}($ e)go sp(a)s(itel)a $h(r b s t) a \cdot$ sice primima sut’ br(a)tie milêiša . $i$ da v rêsnotu vêrovali se biše ${ }_{\mathrm{COND}}$ stvorena $\cdot i$ obak' pro znamenie nam' nêčto $\hat{e}$ laûtb $_{\mathrm{PRS}}$ (BrVO 144a) prvi se konjunktiv prezenta prevodi kondicionalom, a drugi prezentom.

Konjunktiv imperfekta prevodi se kondicionalom: Et iussit aedificari ... ita ut obliviscerentur $_{\text {SBJV.IMPERF }}$ legem, et immutarent SBJV.IMPERF $_{\text {omnes iustificationes }}$ Dei (1Mach 1,50-51): i povelê sazdati ... tako da zabili bi ${ }_{\mathrm{COND}}$ vsa i izmênili $b i_{\mathrm{COND}}$ vsa opravdaniê b(o)žiê (BrVO 409c), prošlim vremenima: accensus est ignis magnus, ita ut omnes mirarentur ${ }_{\text {SBJV.IMPERF }}(2 \mathrm{Mach} 1,22)$ : važga se oganb velikb $\cdot$ tako da vsi čuêhu $u_{\mathrm{IMPERF}}$ se (BrVO 422d).

Konjunktiv pluskvamperfekta prevodi se aoristom: ita ut sacerdotes iam non circa altaris officia dediti essent ${ }_{\mathrm{SBJV.PLPF}}$ (2Mach 4,14): tako da erêi ûže ne pri ol'tarêhb $\cdot$ dano bi $i_{\mathrm{AOR}}(\mathrm{BrVO} 427 \mathrm{c})$.

\section{Pogodbene rečenice}

Pogodbene rečenice u latinskome se uvode veznicima si ('ako'), nisi i si non ('ako ne'). Glagolski oblici u tim rečenicama ovise o stupnju vjerojatnosti ostvarenja pogodbe koja se izriče u zavisnoj surečenici, tj. o tome je li riječ o stvarnoj, mogućoj ili nestvarnoj rečenici. U stvarnim pogodbenim rečenicama u pravilu dolaze indikativni oblici, u mogućim pogodbenim rečenicama konjunktiv prezenta te rjeđe konjunktiv perfekta, a u nestvarnim pogodbenim rečenicama konjunktiv imperfekta za sadašnjost te konjunktiv pluskvamperfekta za prošlost. 
$\mathrm{U}$ hrvatskome crkvenoslavenskom tipičan je veznik pogodbenih rečenica $a \hat{c} e$, a katkad se u tekstovima pojavljuje i hrvatski veznik ako (Gadžijeva i dr. 2014: $356)$.

Tipični veznik zanijekanih pogodbenih rečenica nisi najčešće se prevodi s aĉe ne, najčešće u tome poretku, tj. niječnica ne niječe neki konkretan rečenični dio, npr. predikat, nego cijelu rečenicu: ${ }^{29}$ nisi forte rex auream virgam ad eum tetenderit pro signo clementiae, atque ita possit vivere (Est 4,11): ace ne k(a)ko c(êsa)rb zlatô̂ palicê̂ $k$ nemu prostrlb bud(e)t' za zn(a)m(e)nie pom(i)lovan'ê tre t(a)ko možetb žiti ( $\left.\mathrm{BrN}_{2} 237 \mathrm{~b}\right)$.

U korpusu se moguće pogodbene rečenice pojavljuju rijetko i to gotovo isključivo u Reguli sv. Benedikta. U većini je primjera konjunktiv prezenta preveden ili aoristom ili prezentom. Budući da se konjunktivi u mogućim rečenicama prevode indikativnim oblicima, u prijevodu se gubi značenjska razlika između mogućih i stvarnih rečenica. Rjeđe se pogodbene rečenice prevode i drugim vrstama rečenica: ut psalmum aut lectionem vel alium quid non praesumat in oratorio imponere, nisi iterum abbas iubeat. (Reg. s. Benedicti): da p(i)sma ni lekcie ili čto lûbo v molstiri $\cdot$ ne počni ot službe $\cdot$ doklê opatb ne zapovi (RegBen $29 \mathrm{v})$.

Nestvarne se pogodbene rečenice i s konjunktivom imperfekta i s konjunktivom pluskvamperfeka najčešće prevode kondicionalom I. u objema rečenicama te veznikom ace ili ako (Mihaljević 1990): quam felix essem SBJv.IMPerF $_{\text {, quam mihi }}$ cuncta prospera advenissent $_{\mathrm{SBJV.PLPF}}$ si mulier respiraret SBJV.IMPERF $_{\text {et mecum }}$

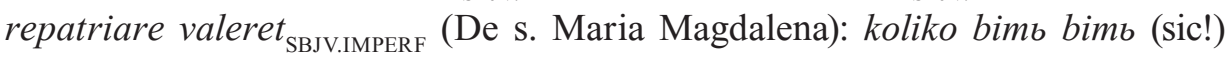
veselb bilb $_{\mathrm{COND}}$ ako žena moê oživela bi $i_{\mathrm{COND}}$ i sa mnô̂ vzvratila se bi $i_{\mathrm{COND}}(\mathrm{CŽg}$ $111 \mathrm{v})$ / koliko m' veselb bilb ${ }_{\mathrm{COND}} \cdot i$ koliko sa p(u)tb radostan' bil' bimb ${ }_{\mathrm{COND}}$ ako žena moê oživila bi $i_{\mathrm{COND}} \cdot$ is sa m’nô̂ vratiti $i_{\mathrm{INF}}$ se mog'la bi $i_{\mathrm{COND}}$ (CIvan 118r).

U primjeru Si non esset $t_{\mathrm{SBJVIIMPEF}}$ malefactor, non tibi eum tradidissemus ${ }_{\mathrm{SBJV} . \mathrm{PLPF}}$ (Ev. Nicod. III, 1): ace bi ne bilb ${ }_{\mathrm{COND}}$ zlêdêi $\cdot$ ne bim' prêdali ${ }_{\mathrm{COND}}$ ego tebê (FgNic 2cd) nestvarna je rečenica uvedena veznikom si non, u zavisnoj je surečenici konjunktiv imperfekta, a u glavnoj konjunktiv pluskvamperfekta. Veznik se prevodi s aĉe uz niječnicu koja stoji ispred participskoga dijela kondicionala. Glagoli su prevedeni kondicionalom.

29 O negaciji v. Kovačević 2016. 
Budući da se nestvarne rečenice prototipno prevode s veznicima ako i aĉe i kondicionalom, u prijevodu postaju moguće rečenice.

\section{Poredbene rečenice}

U poredbenim (usporedbenim) rečenicama, ovisno o tome je li riječ o stvarnoj usporedbi, u latinskome se upotrebljavaju i indikativ i konjunktiv. Kad je riječ o stvarnoj radnji, u rečenicama se pojavljuju korelativne riječi (npr. quantus tantus, qualis - talis, quot - tot...). U poredbenim se rečenicama pojavljuju i poredbeni veznici ut, sicut, quemadmodum, a u glavnoj rečenici stoje korelativi ita, sic, item. U gramatici hrvatskoga crkvenoslavenskog jezika kao tipičan se veznik poredbenih i načinskih rečenica navodi veznik jakože. ${ }^{30}$

U primjeru Ne forte quemadmodum panis vita est, ita etiam panis mors sit (Hom. s. Ambrosii ep.): no čto est' vkusiti semrti i da si bo nêkim' zakonom' hlêbb život' est' · têžde oĉe hlêbb semrtb budet' (BrVO 170b) poredbena se rečenica ne prevodi doslovno, nego je veznik quemadmodum preveden izrazom nêkim' zakonom'. U tome se tekstu nekoliko puta veznik quemadmodum pojavljuje kao veznik zavisnoupitnih rečenica i u njima se prevodi izrazom kim zakonom, pa je i ovaj primjer vjerojatno preveden analogijom prema tim rečenicama. Tu se veznik zapravo pri prevođenju kalkira jer prevoditelj prvi njegov dio povezuje s odnosnom zamjenicom, a drugi s riječju modum. U primjeru quasi per Coelesyriam et Phoenicen civitates esset ${ }_{\text {SBJV.IMPERF }}$ peragraturus (2Mach 3,8): vistinu lêki po celezini $\cdot$ i felicê gradê bil bi proiti $i_{\mathrm{INF}}$ imêlb $_{\mathrm{COND}}\left(\right.$ BrVat $\left._{5} 227 \mathrm{~d}\right)$ konjunktiv imperfekta perifrastične konjugacije aktivne preveden je kondicionalom glagola imêti s infinitivom.

Uz veznik qualiter konjunktiv prezenta prevodi se prezentom: Privatis diebus qualiter matutini agantur $_{\mathrm{SBJV.PRS}}$ (Reg. s. Benedicti): kako se v' ine dni ûtrn'na slava tvoritb $_{\mathrm{PRS}}$ (RegBen 20r).

Uz tamquam stoje konjunktivi prošlih vremena koji se prevode kondicionalom:

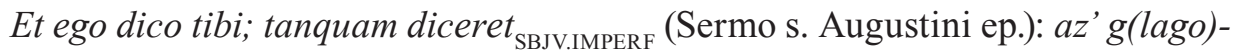

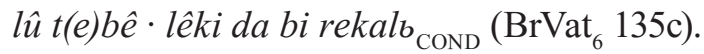

\footnotetext{
${ }^{30}$ Gadžijeva i dr. 2014: 354.
} 


\section{Odnosne rečenice}

Latinske odnosne rečenice s veznikom qui, quae, quod u latinskome najčešće stoje s indikativom, a uglavnom se prevode atributnim rečenicama s veznikom iže, êže, ě̌e ili kontrahiranim veznikom $k i, k a, k o .^{31}$

Relativno je povezivanje pojava u latinskome kad na početku rečenice umjesto pokazne zamjenice stoji odnosna jer se njome izravno povezuje s prethodnom rečenicom. Na hrvatski crkvenoslavenski odnosna se zamjenica prevodi doslovno zamjenicom iže, êže, ěze. U hrvatskome crkvenoslavenskom zamjenica iže, êže, eže zamjenjuje i osobnu zamjenicu, pa može doći samostalno na počet$\mathrm{ku}$ rečenice $\mathrm{u}$ tome značenju. $\mathrm{U}$ rečenicama s relativnim povezivanjem ono se katkad prevodi doslovno sa zamjenicom ki, ka, ko, koja ne može biti pokazna: Quae cum audisset, turbata est in sermone eius, et cogitabat, qualis esset ista salutatio. (Officium b. Mariae in adventu): ka gda sliša smete se o sl(o)vesi ego i mišlaše kakovo bilo bi sie pozdravlenie (CPar 192v). Relativno je povezivanje često i uz poslijelog radi: propter quod et accidit (2Mach 5,17): česo radi $i$ priklûči se (BrVO 430b).

Odnosna rečenica u latinskome uglavnom stoji u indikativu jer označuje i pobliže određuje nešto stvarno. Međutim, u odnosnim se rečenicama pojavljuje i konjunktiv ako je riječ o rečenicama u kojima se izražava značenje koje bi i u jednostavnoj rečenici bilo izrečeno konjunktivom, ako rečenica ovisi o rečenici $\mathrm{u}$ kojoj je predikat u konjunktivu (attractio modi) te ako zavisna surečenica ima smisao koji nije isključivo odnosan (ako izražava namjeru, uzrok, posljedicu, dopuštanje...). Konjunktiv prezenta prevodi se prezentom: Quod manducemus SBJv. $_{\text {. }}$ PRS (Vita Adae et Evae): čto êsti načnem, ${ }_{\text {PRS }}$ (CŽg 31r). Konjunktiv imperfekta prevodi se prezentom: non inveni neminem in quem oporteret ${ }_{\text {SBJVIMPERF }}$ credere (Lectio s. Margaritae): i nikogar' ne naidoh'v koga podobaet ${ }_{\text {PRS }}$ verovati (COxf 24c), prošlim vremenima: ut sumeret unusquisque quod vellet $t_{\text {SBJV.IMPERF }}$ (Est 1,8$)$ : da priem'letb edinb každo čto hotêše ${ }_{\text {IMPERF }}\left(\mathrm{BrN}_{2} 235 \mathrm{a}\right)$ ili kondicionalom: et praeposuit principes populo, qui haec fieri cogerent ${ }_{\text {SBJVIMPERF }}$ (1Mach 1,53): $i$ postavi knezi nad' pl'komb · iže siê tvoriti zapovêdali bi ${ }_{\mathrm{COND}}(\mathrm{BrVO} 409 \mathrm{~d})$.

31 V. Gadžijeva i dr. 2014: 351. 


\section{Zaključak}

Analizom korpusa utvrdili smo da se latinske zavisne rečenice najčešće prevode odgovarajućim tipom rečenica. Odstupanja su uglavnom posljedica nepodudaranja uporabe pojedinih veznika u latinskome, hrvatskome i crkvenoslavenskome. Pod utjecajem latinskoga i prototipne uporabe veznika (npr. cum i $u t$ ) često se jedan tip zavisne rečenice prevodi drugim. Također, pod utjecajem latinskoga nekim se veznicima proširuje značenje i uporaba. Latinski utječe i na odluku koji će od sinonimnih veznika prevoditelj upotrijebiti jer se različiti veznici u latinskome nastoje prevesti različitim veznicima u hrvatskome i crkvenoslavenskome. Tako se primjerice u tekstu Život Marije Magdalene veznikom ere sustavno prevodi veznik quia, a veznicima začb i zane veznik cum. Latinskomu se utjecaju može pripisati prijevod izvorno pogodbenoga veznika $s i$ veznicima aĉe i ako u zavisnoupitnim rečenicama. Zbog izvorno uzročnoga značenja izrični veznik quia najčešće se prevodi veznicima êko i ere. Rjeđe se, također pod utjecajem latinskoga izvornika, veznik quod prevodi odnosnim zamjenicama. Veznici izričnih rečenica quomodo i qualiter zbog svojega se izvornog značenja prevode prilogom kako. Rečenice s veznikom cum najčešće se prevode kao vremenske rečenice čak i kad je riječ o uzročnim ili dopusnim rečenicama. Pri prevođenju latinskih dopusnih rečenica uglavnom se vjerno oponaša struktura latinskoga veznika. Veznik etiamsi prevodi se kalkom takožde aĉe i oĉe aĉe, a veznik etsi s pomoću aĉe $i$ ili ako $i$. Dopusni veznik licet ne prepoznaje se kao veznik, nego se prevodi glagolom. Pri prevođenju pogodbenih rečenica u prvome je planu oponašanje latinske strukture, a ne jasno izricanje stupnja ostvarivosti radnje pojedine pogodbe. Prevoditelji tako uglavnom ne razlikuju stvarne i moguće rečenice te moguće i nestvarne jer se u mogućim rečenicama konjunktivi prototipno prevode indikativnim oblicima, a u nestvarnima konjunktivi prošlih vremena kondicionalom. Veznik nisi prevodi se veznikom aĉe uz koji se pojavljuje niječnica koja mu neposredno prethodi ili ga slijedi, a ne niječe predikat, što bi bio prototipan način nijekanja čitave surečenice. Latinski je utjecaj vidljiv i u primjerima prijevoda odnosnih rečenica s relativnim povezivanjem koje se prevodi zamjenicom $k i, k a, k o$ na početku rečenice kao da je riječ o pokaznoj zamjenici.

Budući da ni hrvatski ni crkvenoslavenski nemaju konjunktiva, prevoditelji te oblike prevode različito. Konjunktiv prezenta najčešće se prevodi indikativom. 
Kao prijevodna se istovrijednica konjunktivu u korpusu rijetko pojavljuje imperativ, koji se u literaturi katkad navodi kao istovrijednica latinskomu konjunktivu. Prošli se konjunktivi često prevode kondicionalom, osobito konjunktivi imperfekta i pluskvamperfekta. U većini se rečenica takvo prevođenje može pripisati utjecaju latinskoga jer nije riječ o rečenicama kojima se izriče potencijalnost ili želja tipična za kondicional. Kondicional se pod utjecajem latinskoga pojavljuje kao prijevodna istovrijednica konjunktiva imperfekta i rjeđe pluskvamperfekta u zavisnoupitnim, zahtjevnim, izričnim, uzročnim, posljedičnim i poredbenim rečenicama. Konjunktiv se kondicionalom prevodi i u namjernim rečenicama, ali to nije odstupanje od hrvatske crkvenoslavenske norme jer se u namjernim rečenicama općenito može pojaviti kondicional. Međutim, vjerojatno je pod utjecajem latinskoga kondicional u namjernim rečenicama znatno češći. Konjunktivi imperfekta i pluskvamperfekta u vremenskim rečenicama najčešće se prevode prošlim glagolskim oblicima, što svjedoči o tome da prevoditelji razumiju da u njima konjunktiv služi za izricanje prošle radnje. Katkad se, osobito u biblijskim tekstovima, pod utjecajem latinskoga konjunktivi prošlih vremena ipak prevode kondicionalom. Ti se konjunktivi i u odnosnim rečenicama prevode kondicionalom, ali tu nije riječ samo o latinskome utjecaju jer se i u hrvatskome crkvenoslavenskom u odnosnim rečenicama može pojaviti kondicional.

\section{Popis kratica}

BrBer $_{1}$ - I. beramski brevijar, kraj 14. st.

$\mathrm{BrBer}_{2}-$ II. beramski brevijar, 15. st.

$\mathrm{BrN}_{2}$ - II. novljanski brevijar, 1495.

BrVat $_{5}$ - Vatikanski brevijar Illirico 5, sredina 14. st.

BrVat $_{6}$ - Vatikanski brevijar Illirico 6, sredina - kraj 14. st.

BrVO - Brevijar Vida Omišljanina, 1396.

CIvan - Ivančićev zbornik, 14. - 15. st.

COxf - Oksfordski zbornik, 15. st. 
CPar - Pariški zbornik, 1375.

CŽg - Žgombićev zbornik, 16. st.

FgEpist - Epistula o nedjelji, 13. st.

FgNic - Pazinski fragment Nikodemova evanđelja, početak 14. st.

RegBen - Regula sv. Benedikta, kraj 14. st.

\section{Literatura:}

BAdurina StiPČEviĆ, Vesna. 1999. Najstariji tekst hrvatskoglagoljskih Makabejskih knjiga. Slavia 68/2. 259-265.

Badurina Stipčević, Vesna. 2004. The Old Testament Book of Esther in Croatian Glagolitic Vatican Illirico 5 Breviary from 14th century. Palaeoslavica XII/2. 5-39.

Badurina StipČević, Vesna. 2006. Knjige o Makabejcima u hrvatskoglagoljskoj književnosti: Prva Knjiga o Makabejcima u hrvatskoglagoljskim brevijarima. Slovo 54-55. $5-126$.

Badurina StiPČEvić, Vesna. 2008. Još jedna glagoljska verzija Protoevanđelja Jakovljeva. Slovo 56-57. 75-92.

Badurina StipČević, Vesna. 2009. Knjige o Makabejcima u hrvatskoglagoljskoj književnosti: Druga knjiga o Makabejcima u hrvatskoglagoljskim brevijarima. Slovo 59. $1-75$.

BAdurina StiPČEvić, Vesna. 2012. Hrvatskoglagoljska Knjiga o Esteri. Matica hrvatska. Zagreb.

Badurina StiPČEvić, Vesna. 2013. Hrvatska srednjovjekovna proza I. Legende i romani. Matica hrvatska. Zagreb.

Catford, John Cunnison. 1965. A Linguistic Theory of Translation. Oxford University Press. Oxford.

Cuzzolin, Pierluigi. 1994. Sull'origine della costruzione dicere quod. Aspetti sintattici e semantici. La Nuova Italia. Firenca.

Cuzzolin, Pierluigi. 2013a. Some remarks on quia as a subordinator after verbs of saying and thinking. Journal of Latin Linguistics 12/1. 51-69.

Cuzzolin, Pierluigi. 2013b. The Latin construction dicere quod revisited. Graeco-Latina Brunensia 18/1. 23-38.

DürRIgl, MariJa-ANa. 2013. Hrvatska srednjovjekovna proza II: apokrifi, vizije, prenja, Marijini mirakuli. Matica hrvatska. Zagreb. 
Eterović, Ivana; Vela, Jozo. 2013. Sintaktičke funkcije participa u Misalu hruackome Šimuna Kožičića Benje. Slovo 63. 1-22.

ETYMOLOGICKÝ 1999. = Etymologický slovník jazyka staroslověnského 9. Academia. Praha. ETYMOLOGickÝ 2002. = Etymologický slovník jazyka staroslověnského 11. Academia. Praha. GADŽIJeVA, SofIJA I DR. 2014. Hrvatski crkvenoslavenski jezik. Hrvatska sveučilišna naklada - Staroslavenski institut. Zagreb.

Galabov, Ivan. 1973. Das Altbulgarische und das Latein im europäischen Mittelalter: zur Problematik der übernationalen Kultursprachen; Antrittsvorlesung gehalten am 14. Dez. 1971 an d. Univ. Salzburg. Salzburger Universitätsreden. Salzburg.

Gortan, Veljoo; Gorski, Oton; PAuŠ, PAVAo. ${ }^{12} 2005$. Latinska gramatika. Školska knjiga. Zagreb.

GRICKAT, IRENA. 1972. Aktualni jezički i tekstološki problemi u starim srpskim ćirilskim spomenicima. Narodna biblioteka SR Srbije. Beograd.

Herman, József. 2000. Vulgar Latin. The Pennsylvania State University Press. Pennsylvania.

IVIR, Vladimir. 1978a. Teorija i tehnika prevođenja: udžbenik za I. god. pozivnousmerenog obrazovanja i vaspitanja srednjeg stupnja prevodilačke struke. Centar „Karlovačka gimnazija" Sremski Karlovci. Sremski Karlovci.

IVIR, VLADIMIR. 1978b. Teorija i tehnika prevođenja: udžbenik za II. god. pozivnousmerenog obrazovanja i vaspitanja srednjeg stupnja prevodilačke struke. Centar „Karlovačka gimnazija" Sremski Karlovci. Sremski Karlovci.

IVIR, V LADIMIR. 1990. Languages in contact through translation. Languages in contact: proceedings of the Symposium. Ur. Filipović, Rudolf; Bratanić, Maja. Institut za lingvistiku. Zagreb.

KeIPERT, Helmut. 1987. Kirchenslavisch und Latein. Über die Vergleichbarkeit zweier mittelalterlicher Kultursprachen. Sprache und Literatur Altrußlands. Ur. Birkfellner, Gerhard. Aufsatzsammlung. Münster.

KeIPERT, Helmut. 1996. Das Lateinische in der Geschichte der russischen Sprache. Eurolatein. Ur. Munske, Horst Haider; Kirkness, Alan. Max Niemeyer Verlag. Tübingen.

KovačEvić, AnA. 2016. Negacija od čestice do teksta: Usporedna i povijesna raščlamba negacije u hrvatskoglagoljskoj pismenosti. Staroslavenski institut. Zagreb.

Kranich, Svenja. 2014. Translations as a Locus of Language Contact. Translation: A Multidisciplinary Approach. Ur. House, Juliane. Hamburg University, Germany Hellenic American University, Greece. Hamburg - Atena.

Kravar, Miroslav. 1978. Zur Futurperiphrase budem + Infinitiv im Serbokroatischen. Slavische Studien zum VIII. Internationalen Slavistenkongress in Zagreb. Böhlau-Verlag. Köln - Wien. 
Kroch, Anthony. 2001. Syntactic change. The Handbook of Contemporary Syntactic Theory. Ur. Baltin, Mark; Collins, Chris. Blackwell. Oxford.

Laviosa, Sara. 2003. Corpora and Translation Studies. Corpus-based Approaches to Contrastive Linguistics and Translation Studies. Ur. Granger, Sylviane; Lerot, Jacques; Petch-Tyson, Stephanie. Rodopi. Amsterdam - New York.

MatěJKa, Ladislav. 1966. The Creative Usage of Church Slavonic. To honor Roman Jakobson. Essays on the Occasion of His Seventieth Birthday. Mouton. The Hague Paris. 1295-1330.

MatěJKa, Ladislav. 1968. On Translating from Latin into Church Slavonic. American Contributions to the Sixth International Congress of Slavists. Mouton. The Hague Paris. 247-274.

MatĚJKa, LAdislav. 1971. K syntaxi církveněslovanských překladů z latiny. Studia Palaeoslovenica. 227-236.

Minaljević, AnA. 2014. Hrvatskoglagoljski Život Marije Magdalene u odnosu na latinski predložak. Ricerche slavistiche 12/58. 213-293.

Minaluević, Ana. 2018. Sintaksa hrvatskoglagoljskih tekstova prevedenih s latinskoga. Doktorski rad. Filozofski fakultet Sveučilišta u Zagrebu. 470 str.

Minaljević, Milan. 1990. Veznici ašće i ako u hrvatskoglagoljskim tekstovima. Suvremena lingvistika 29-30. 99-117.

Minaljević, Milan. 2011a. Dopune percepcijskih glagola u hrvatskome crkvenoslavenskom jeziku. Suvremena lingvistika 37/72. 187-200.

Minaljević, Milan. 2011b. Verba Dicendi in Croatian Church Slavonic. Zbornik Matice srpske za filologiju i lingvistiku LIV, 1. 63-77.

Minaljević, Milan. 2011c. Položaj crkvenoslavenskoga jezika u hrvatskoj srednjovjekovnoj kulturi. Zbornik na trudovi od Megjunarodniot naučen sobir Sveti Naum Ohridski i slovenskata duhovna, kulturna i pismena tradicija (organiziran po povod 1100-godišninata od smrtta na sv. Naum Ohridski). Ur. Velev, Ilija i dr. Univerzitetot Sv. Kiril i Metodij. Skopje. 229-238.

Mihaljević, Milan. 2016. Uzročne konstrukcije u hrvatskome crkvenoslavenskom jeziku. Zbornik radova Šestoga hrvatskoga slavističkoga kongresa održanoga u Vukovaru i Vinkovcima od 10. do 13. rujna 2014. Ur. Botica, Stipe i dr. Hrvatsko filološko društvo. Zagreb.

Minaljević, Milan. 2004. Veznik „da” u hrvatskoglagoljskim tekstovima. Slavia meridionalis 4. 9-34.

Minaljević, Milan. 2006. Sintaktička svojstva najstarijih hrvatskoglagoljskih tekstova. Mnogokratnite prevodi v južnoslavjanskoto srednovekovie. Ur. Taseva, Lora; Marti, Roland; Jovčeva, Marija. Goreks Pres. Sofija. 
Minaljević, Milan. 2008. The Particle eda in Croatian Glagolitic Texts. Varia Slavica: Sborník príspěvků $k$ 80. narozeninám Radoslava Večerky. Ur. Janyšková, Ilona; Karlíková, Helena. Nakladatelství Lidové noviny. Praha.

Minaljević, Milan. 2009. Hrvatski crkvenoslavenski jezik. Povijest hrvatskoga jezika. 1. knjiga: Srednji vijek. Ur. Bičanić, Ante. Croatica. Zagreb.

Mihaljević, Milan; Reinhart, Johannes. 2005. The Croatian Redaction: Language and Literature. Incontri linguistici 28. 31-83.

Nida, Eugene Albert; Taber, Charles Russell. 2003. The Theory and Practice of Translation. Brill. Leiden - Boston.

Norberg, Dag. 1968. Manuel pratique de latin medieval. Picard. Paris.

PÁclovÁ, IlonA. 1970. K otázce vlivu řečtiy na církevněslovanské památky s latinskou předlohou. Studia Balkanica Bohemo-Slovaca. 277-284.

Pinkster, Harm. 2015. Oxford Latin Syntax: Volume 1: the Simple Clause. Oxford university press. Oxford.

Prince, Ellen F. 1988. On pragmatic change: the borrowing of discourse functions. Journal of Pragmatics 12. 505-518.

Prince, Ellen F. 1992. On syntax in discourse, in language contact situations. Text and contect: Cross-disciplinary perspectives on language study. Ur. Kramsch, Claire; McConnell-Ginet, Sally. D C Heath \& Co. Lexington, Mass.

Prince, Ellen F. 1998. The borrowing of meaning as a cause of internal syntact ic change. Historical Linguistics, Dusseldorf, 10-17 August 1997. Ur. Schmid, Monika; Austin, Jennifer; Stein, Dieter. John Benjamins. Amsterdam - Philadelphia.

RCJHR 2000. = Rječnik crkvenoslavenskoga jezika hrvatske redakcije. I. sv. A-vrêdb. Staroslavenski institut. Zagreb.

RCJHR 2014. = Rječnik crkvenoslavenskog jezika hrvatske redakcije. II. sv. vrêdbnbzapovêdnica. Staroslavenski institut. Zagreb.

Sakel, Jeanette; Matras, Yaron. 2007. Modelling contact-induced change in grammar. Aspects of language contact: New theoretical, methodical and empirical findings with special focus on romanisation processes. Ur. Stolz, Thomas i dr. Mouton de Gruyter. Berlin.

Sankoff, Gillian. 2001. Linguistic outcomes of language contact. Handbook of Sociolinguistics. Ur. Trudgill, Peter; Chambers, J. K.; Schilling-Estes, Natalie. Basil Blackwell. Oxford.

Silva-Corvalán, CARmen. 1993. On the per meabil it y of grammar s: evidence from Spanish and English contact. Selected papers from the 21 st symposium on Romance Languages. Ur. Ashby, William i dr. John Benjamins Publishing Company. Amsterdam.

Silva-Corvalán, Carmen. 1994. Language contact and change: Spanish in Los Angeles. Clarendon Press. Oxford. 
Silva-Corvalán, Carmen. 1998. On borrowing as a mechanism of syntactic change. Romance linguistics: Theoretical perspectives. Ur. Schwegler, Armin; Tranel, Bernard; Uribe-Extebarria, Myriam. John Benjamins. Amsterdam.

Silva-Corvalán, CARmen. 2008. The limits of convergence in language contact. Journal of Language Contact. Thema 2. 213-224.

TANDARIĆ, Josip. 1993. Hrvatsko-glagoljska liturgijska književnost. Kršćanska sadašnjost, Provincijalat franjevaca trećoredaca. Zagreb.

Thomason, Sarah; Kaufman, Terrence. 1988. Language contact, creolization, and genetic linguistics. University of California Press. Berkeley - Los Angeles - Longon.

Thomason, SARAh. 2001. Language contact. Edinburgh: Edinburgh University Press.

Thomason, Sarah. 2010. Contact explanations in linguistic. The hadbook of langage contact. Ur. Hickey, Raymond. Blackwell Publishing Ltd.

Touratier, Christian. 1994. Syntaxe latine. Peeters. Leuen.

Turkalu, LuciJa. 2008. Život Adama i Eve u Žgombićevu i Fatovićevu zborniku. Slovo 56-57. 579-593.

Winford, Donald. 2003. An Introduction to Contact Linguistics. Blackwell. Malden.

\section{Latin Influence on the Syntax of Dependent Sentences in Croatian Glagolitic Texts}

\section{Abstract}

This paper analyses the influence of Latin on the syntax of Croatian Glagolitic texts translated from Latin. While translating dependent sentences from Latin into Croatian Church Slavonic, the translators usually literally translated sentences without changing their structure. However, two major problems occur in such translations. The first is how to translate the conjunctive, which occurs in many dependent sentences and which has no formal equivalent in Croatian Church Slavonic. The second is how to translate certain conjunctions, as the meaning and function of certain Latin conjunctions does not correspond with that of conjunctions in Croatian Church Slavonic. While translating these conjunctions, the same Latin conjunctions can occur in different classes of dependent sentences, and they are translated with different Croatian Church Slavonic conjunctions in different contexts. Problems arise when translating very common Latin conjunctions such as $u t, c u m$, and quia as the translators often use the typical meaning of the Latin conjunction, thus resulting in translation errors. The paper focuses on the usage of tense and conjunctions in dependent clauses, the relationship between declarative sentences and constructions with the infinitive, and some other cases of Latin influence on the syntax of dependent clauses. The corpus includes the apocryphal texts: Vita 
Adae et Evae, Evangelium Nicodemi, Protoevangelium Jacobi, hagiographies: Lectio B. Margaritae, Tractatus de purgatorio sancti Patricii, Vita Mariae Magdalenae, the Biblical books of Esther and the Maccabees, and the service in honor of st. Anthony.

Ključne riječi: sintaksa, hrvatski crkvenoslavenski, latinski, prevođenje, zavisne rečenice Keywords: syntax, Croatian Church Slavonic, Latin, translation, dependant sentences 